\title{
Research on the Physico-Chemical Properties of Soils Locality Daneasa, Olt County for Sustainable
}

\section{Agriculture}

\author{
Anca-Luiza Stănilă (Corresponding author) \\ Department research in soil science, agrochemical and environmental protection \\ Laboratory of soil sciences and sustainable development \\ National Research Institute for Soil Science \\ Agrochemistry and Environment Protection - ICPA \\ 61 Mărăşti Blvd, District 1, 011464, Bucharest, Romania \\ E-mail: luizastanila2011@yahoo.com
}

Received: July 4, 2020

Accepted: July 18, 2020

Published: July 21, 2020

Doi: 10.5296/jab.v8i2.17396

URL: https://doi.org/10.5296/jab.v8i2.17396

\begin{abstract}
The territory studied is situated in the South-Eastern part of Olt County, it is part of the great unit of the Romanian Plain, that is, from the subunit of Boianu Plain (Calmatui Plain), being located on the left bank of Olt River. Locality presents a predominant relief of plain low altitude that is characterized by alluvio-proluvial plains moderately fragmented with local terraces, covered with loess-like deposit but relief of saucer.

The soil cover of the territory under study is the direct reflection of all environmental factors, each having a role in the pedogenetic processes. Thus, the climate conditions have ensured the solification direction, taking into account the temperature regime and the specific precipitation of the Boianu Plain.

Steppe vegetation was the supply of organic matter and biomass, because the hydrological regime is deficient, but especially the lithological substrate (loess) to steer solification to types characteristic of the cernisols class.

Under the influence of environmental factors and pedogenetic processes within the locality Daneasa it formed a wide range of soils, namely: protisols, cernisols, luvisols, hydrisols and salsodisols.
\end{abstract}


Keywords: Soil resources, Physico-chemical properties, Sustainable agriculture, Boianu Plain, Improvement work

\section{Introduction}

Locality Daneasa is among the regions nature and diversity of natural territorial complex components ensures optimum user to obtain agricultural production and income, the more they are exploited effectively, economically and environmentally existing technologies. A productive agriculture is essential prerequisite for sustainable development of agriculture with multiple objectives, improve livelihoods, with preserving and protecting the natural resource base. All this is not possible without special research, extensive and often lengthy.

Locality Daneasa is located in Olt County, in the Boianu Plain (Calmatui Plain), where there are large interfluve with numerous saucer (Cotet, 1976).

Withen the territory studied is presented formation, development, soils distribution, physical and geographical conditions, main physico-chemical properties, improvement measures and recovery productive potential for sustainable agriculture.

Closely related to formation, development and distribution of soils in the territory, was intended at the outset how the appearance of each factor of the complex territorial analyzing on all the structure, dynamics and function of each of them, as their role directly or indirectly in the soils genesis.

\section{Materials and Methods}

Elementary basic unit of content in soils research from within Locality Daneasa was the soil profile, thus allowing the study of morphological characteristics of the soils. As a result, soils were classified based on intrinsic properties, namely the soil profile, taking into account horizons and diagnostic characters.

In the territory taken in study was applied the ICPA methodology which included a rich land and laboratory, which consisted in exploration the ground cover in large and medium scale, using soil profiles in a network of points with respect to the geological, geomorphologic composition of planning, its hydrography, hydrology and hydrogeology. Also played an important role in vegetation, relief and human activity.

To characterize the physical and chemical were collected numerous soil samples unmodified and modified settlement on which were performed the determinations in the laboratory.

In modified settings, soil samples of $20 \mathrm{~cm}$ thickness were taken in bags, for the chemical characterization to be carried. In natural (unchanged) settings, soil samples were taken using a metal cylinder of known volume $\left(200 \mathrm{~cm}^{3}\right)$ to characterize the physical features, as well as the momentary soil moisture.

The following methods have been used for the physical features:

Determination of particle size fractions (granulometry):

- $\quad$ pipette method fraction $\leq 0.002 \mathrm{~mm}$;

- wet sieving method for fractions 0.002 to $0.2 \mathrm{~mm}$ and dried fractions $>0.2 \mathrm{~mm}$. The results are expressed as a percentage of the remaining material after the pretreatment.

For the textural classes and subclasses, we used the Romanian system, according to the 
Methodology developed for soil studies, ICPA, 1987.

The chemical characteristics were determined using the following methods:

pH: potentiometrically, with glass and calomel combined electrode, in aqueous suspension, at the ratio of $1 / 2,5$.

Humus: wet oxidation (Walkley-Black method, modified) and results expressed in percentage.

Total nitrogen (Nt): Kjeldahl method, decomposition of $\mathrm{H}_{2} \mathrm{SO}_{4}$ at $350^{\circ} \mathrm{C}$, catalysts: potassium sulphate and copper sulphate.

Available phosphorus (mobile): Egner-Riehm-Domingod method and colorimetric dosed with blue molybdenum, according to Murphy-Riley method (ascorbic acid reduction).

Available potassium (mobile): extraction according to Egner-Riehm-Domingo method and dosing by flame photometry.

Map making materials were used following map: Romanian soil map, scale 1:200.000, sheet Slatina. Thus, those maps were scanned, then the images were vectorized. He data were then processed using ArcMap. For each map, the computer result in a "polygon layer" mapping each polygon representing a territorial unit. Cartographic data validation was done by overlapping polygons layer the source data. Each territorial mapping unit, were entered as attributes: soil genetic unit, the surface texture, the parent material, pedogenetic processes and the relief.

\section{Results and Discussion}

The relief of locality Daneasa is composed from: Boianu Plain (Calmatiu Plain), terrace I of Olt (4-7 m) and Olt floodplain (Figure 1) (Posea et al., 2005).

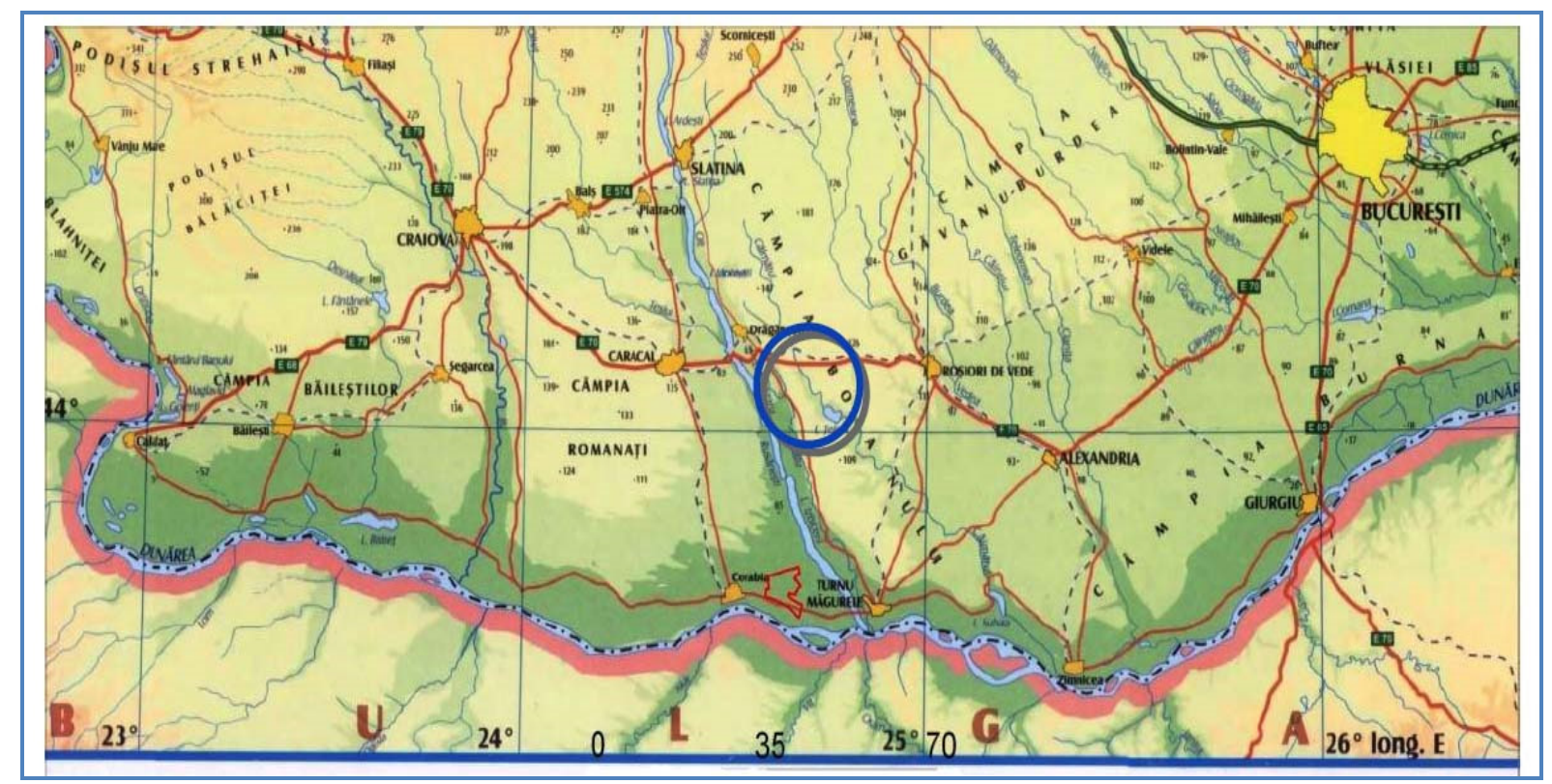

Figure 1. Position of Locality Daneasa in Boianu Plain 
Boianu Plain is characterized by a steep slope which dominates the Olt Valley, accompanied by a strong line of springs from which the villages located south of Draganesti-Olt. This interfluve is also distinguished by a large number of saucer in which they can form lakes.

The plain is fragmented by the Sodol Valley and torrential valleys tributaries. These give it a weak wavy appearance that alternates with interfluve mane (Figure 2).

Saucer have temporary moisture excess short-term, due to the good permeability of loess-like deposit constituting the lithology of the plain zone.

Sodol's slopes are affected by surface erosion from weak to very strong (Figure 3).

Terrace I of Olt has a relative altitude of 4-7 $\mathrm{m}$ and is little represented in the territory studied more in the form of a shoulder, what makes the crossing in the plain zone and the one of floodplain.

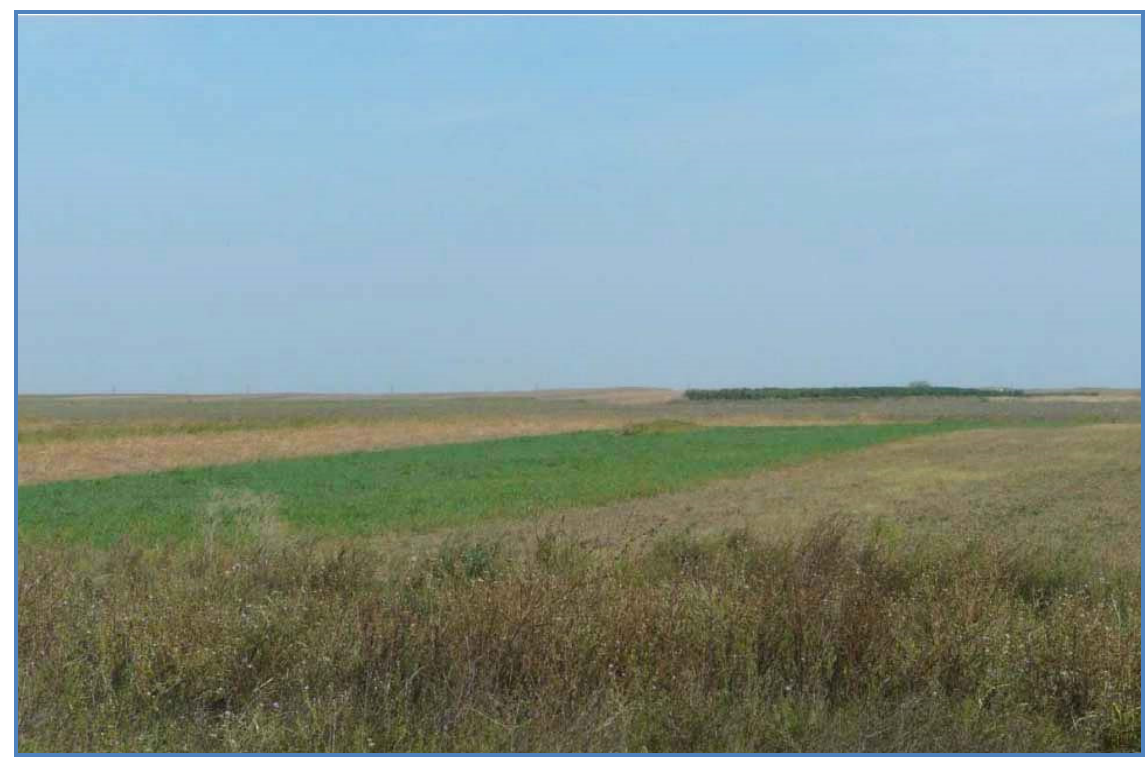

Figure 2. Relief of saucer on Sodol Valley

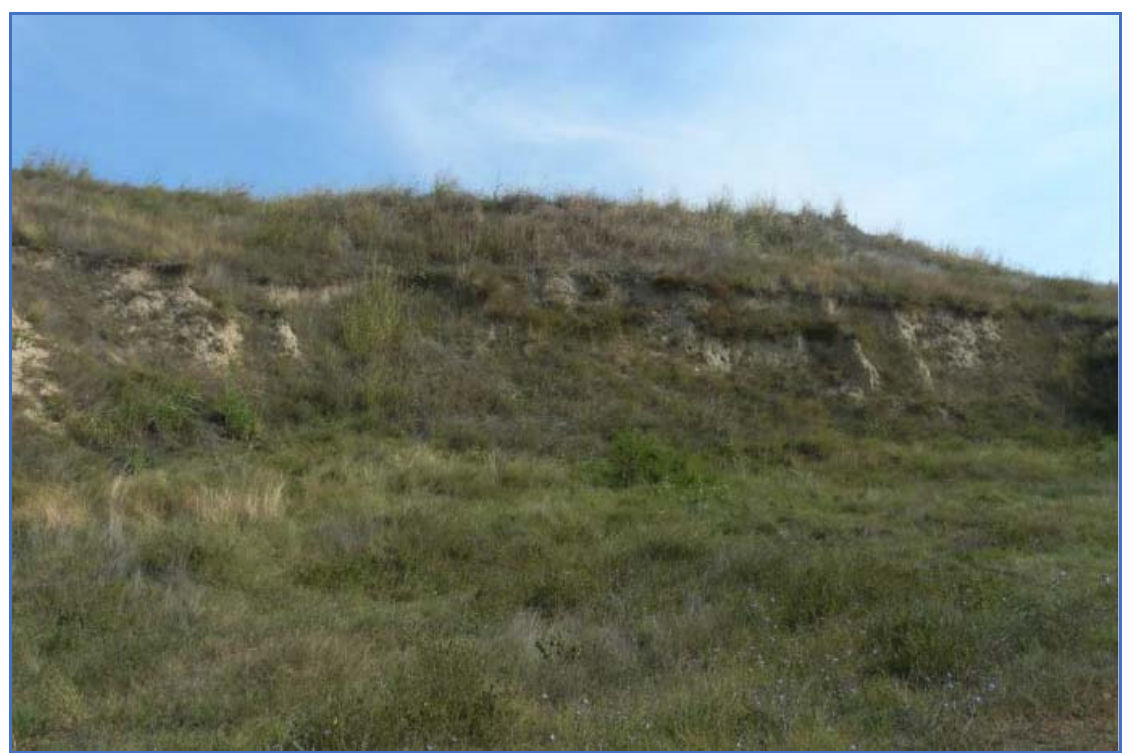

Figure 3. Erosion processes in Sodol Valley 


\section{Macrothink $\Lambda$ Institutem}

Olt floodplain is the form of relief with the largest extent on territory of locality Daneasa. Within it is delineated the depressionary alluvial saddle, the high beam of Olt and the transitional alluvial saddle.

The lithology of surface deposits is closely related to and corresponds to levantine and quaternary formations.

Levantine represented by clays, marls, sands and gravels appears at base of slopes of Sodol Valley.

Quaternary forms the most extensive superficial bedspread and quite varied in terms of genetic and lithologic in which are distinguished the following lithologic complexes (Stănilă et al., 2010):

Loess-like complex occupies the area located on the higher forms of relief (Calmatui Plain) part of the Boianu Plain and terrace I of Olt and comprises both dusty and sandy loess and deluvial clays, which in many sectors are difficult to separate (Figure 4).

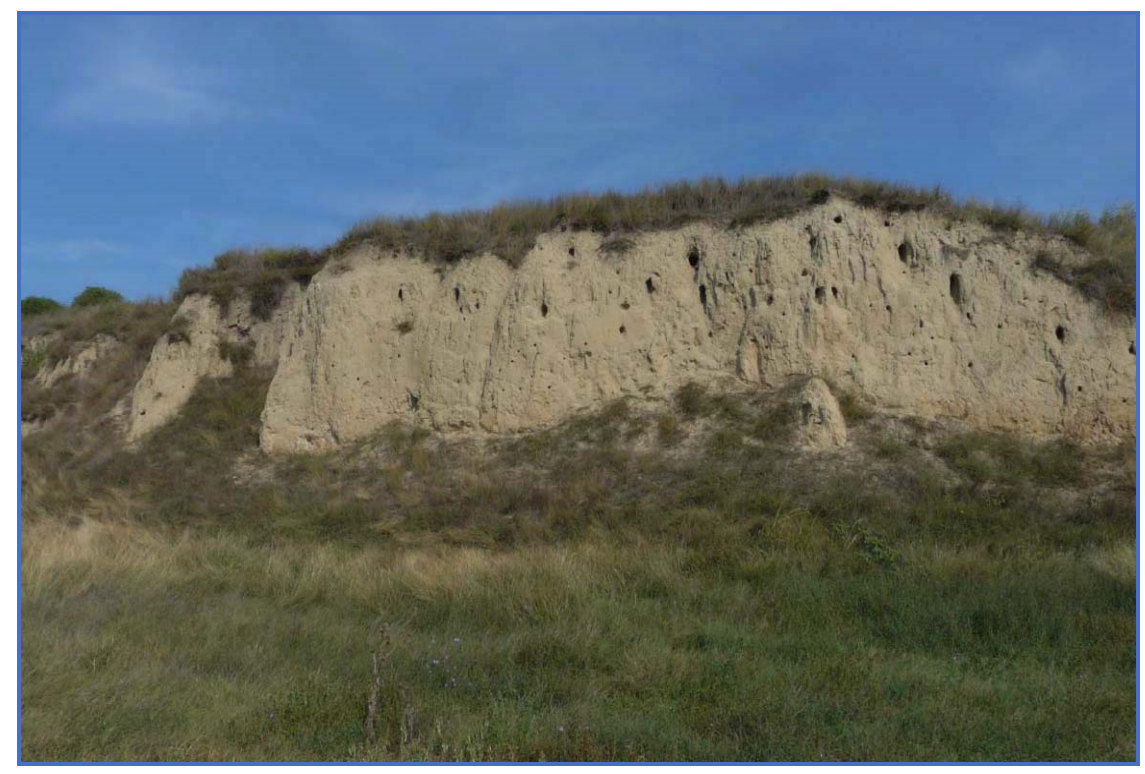

Figure 4. Loess-like deposits in Boianu Plain

Alluvial complex appears in of floodplain the Olt River on the base are found holocene deposits consisting of sands, gravels and boulders covered with sandy and clay alluvials. The thickness of deposits Olt floodplain reach 10-12 m.

From the point of view hydrographic, the territory of Daneasa belongs to hydrographic basin of the Olt River. Olt River flows through the western extremity of the locality, has the course oriented NNV-SSE and totality indigested.

The groundwater is located at depths of more than $20 \mathrm{~m}$ in the Boianu Plain and 10-15 $\mathrm{m}$ on the terraces of Olt. On territory of Daneasa the climate is type temperate-continental with more arid hue due to the waves of dry air in the east, causing harsh winters and dry summers. The average annual temperature is $11.0^{\circ} \mathrm{C}$ at the Slatina Station; the lowest monthly average air temperature was recorded in January, $-1.7^{\circ} \mathrm{C}$ and the highest $22.1{ }^{\circ} \mathrm{C}$, in July. Regarding rainfall we can say that, they have the same continental influence as air temperature, they are 


\section{Macrothink}

Journal of Applied Biotechnology

ISSN 2327-0640

2020, Vol. 8, No. 2

predominantly in the form of rain, but unevenly distributed. Thus, the average annual rainfall amounts at the Slatina Station are $525 \mathrm{~mm}$.

From the data on the vegetation of our country it appears that the region studied belongs to the steppe zone.

Grass vegetation consists of steppe elements, xerophiles (Stănilă, 2006): Botriochloa ischaeum, Festuca valesiaca, Agropyron cristatum, Poa bulbosa, Artemisia austriaca, Cynodon dactylon, Stipa lessingiana, Stipa capillata, Trifolium pratense, Medicago falcata, Melilotus officinalis (Figure 5).

Wood vegetation appears widespread only in the form of clows consisting of: Quercus pubescens, Quercus pedunculiflora, Tilia tomentosa, Populus alba, Populus tremula, etc.

Depending on the conditions and factors that contributed to the formation of the soils, within the territory under investigation the following soils have been identified at class level: protisols, cernisols, luvisols, hydrisols and salsodisols (Ispas \& Stănilă, 2015).

Protisols class comprises the youngest soils, at an early stage of development, formed as a result of repeated sediment deposition, represented by eutric regosols and entic aluviosols (Figure 6).

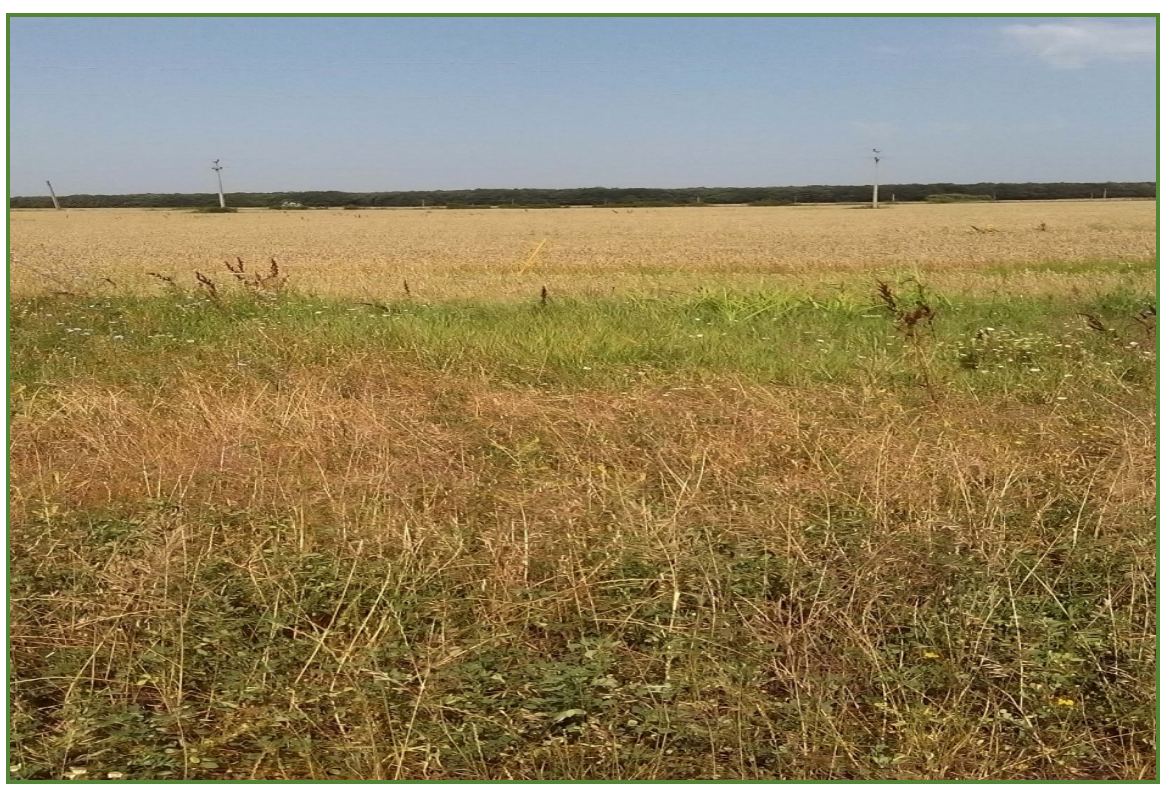

Figure 5. Xerophile vegetation in the southeast of Daneasa 


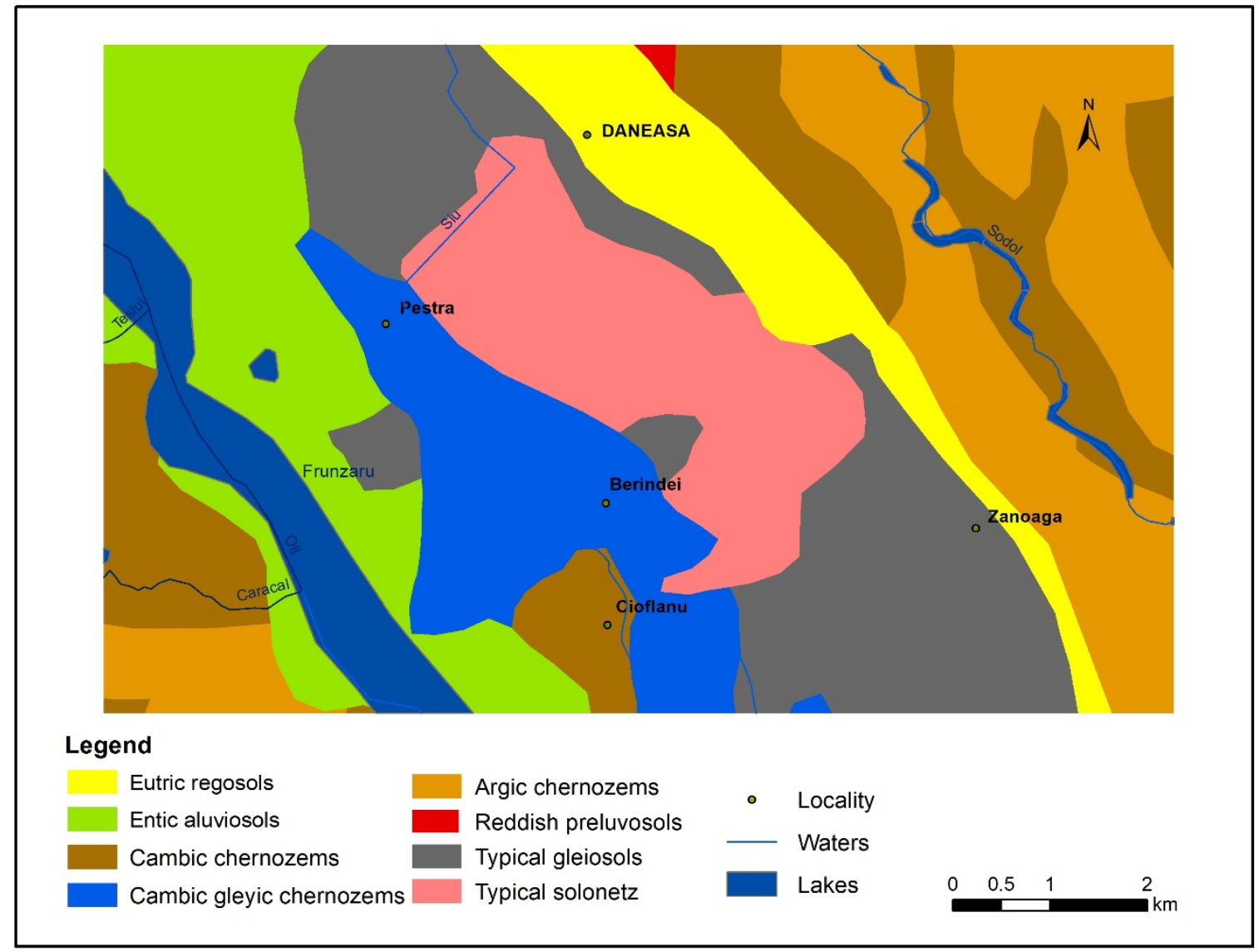

Figure 6. Soils Map of Daneasa

Eutric regosols appear widespread in the strongly inclined slopes on the eluvio-deluvial loamy deposits, with groundwater depth above $10.1 \mathrm{~m}$. Presents a profile of type $A o-A C-C$ moderately developed.

Texture is loamy (21-25\% clay) (Table 1$)$ and the soil reaction is weakly acidic-neutral over the entire soil profile $(\mathrm{pH}=6.4-7.1)$.

The humus content is medium in the surface horizon $(2.3 \%)$ and the humus reserve on the range $0-50 \mathrm{~cm}$ is small. Nutrient supply is medium with total nitrogen (11.0-11.6\%), low phosphorus and potassium (P mobile-14-18 ppm; K mobile-132-160 ppm) (Table 2).

Table 1. Granulometric composition of eutric regosols

\begin{tabular}{|c|c|c|c|c|c|}
\hline \multirow{2}{*}{ Horizon } & \multirow{2}{*}{$\begin{array}{c}\text { Depth } \\
\text { (cm) }\end{array}$} & \multicolumn{4}{|c|}{ Granulometry } \\
\cline { 3 - 6 } & & $\mathbf{< . 0 0 2} \mathbf{~ m m}$ & $\mathbf{0 . 0 0 2 - 0 . 0 2} \mathbf{~ m m}$ & $\mathbf{0 . 0 2 - 0 . 2} \mathbf{~ m m}$ & $\mathbf{0 . 2 - 2 . 0 ~} \mathbf{~ m m}$ \\
\hline Ao & $0-35$ & 21.0 & 25.5 & 53.3 & 0.2 \\
\hline AC & $35-55$ & 22.0 & 28.0 & 49.4 & 0.6 \\
\hline C & $55-100$ & 25.0 & 21.0 & 53.9 & 0.1 \\
\hline
\end{tabular}


Table 2. Chemical properties of eutric regosols

\begin{tabular}{|c|c|c|c|c|c|c|}
\hline Horizon & $\begin{array}{c}\text { Depth } \\
(\mathrm{cm})\end{array}$ & $\begin{array}{c}\text { pH } \\
\left(\mathbf{H}_{2} \mathrm{O}\right)\end{array}$ & $\begin{array}{c}\text { Humus } \\
\%\end{array}$ & $\begin{array}{c}\text { Total } \\
\text { Nitrogen } \\
\%\end{array}$ & $\begin{array}{c}\text { Mobile P } \\
(\mathbf{p p m})\end{array}$ & $\begin{array}{c}\text { Mobile K } \\
\text { (ppm) }\end{array}$ \\
\hline Ao & $0-35$ & 6.4 & 2.3 & 11.6 & 18 & 160 \\
\hline $\mathrm{AC}$ & $35-55$ & 7.0 & 2.2 & 11.4 & 16 & 140 \\
\hline $\mathrm{C}$ & $55-100$ & 7.1 & 1.8 & 11.0 & 14 & 132 \\
\hline
\end{tabular}

Entic aluviosols occur in the Olt floodplain, on aluvial clay deposits, with groundwater between 2-3 m. Presents a profile of type $A o-A C-C_{1}-C_{2}$ moderately developed (Figure 7).

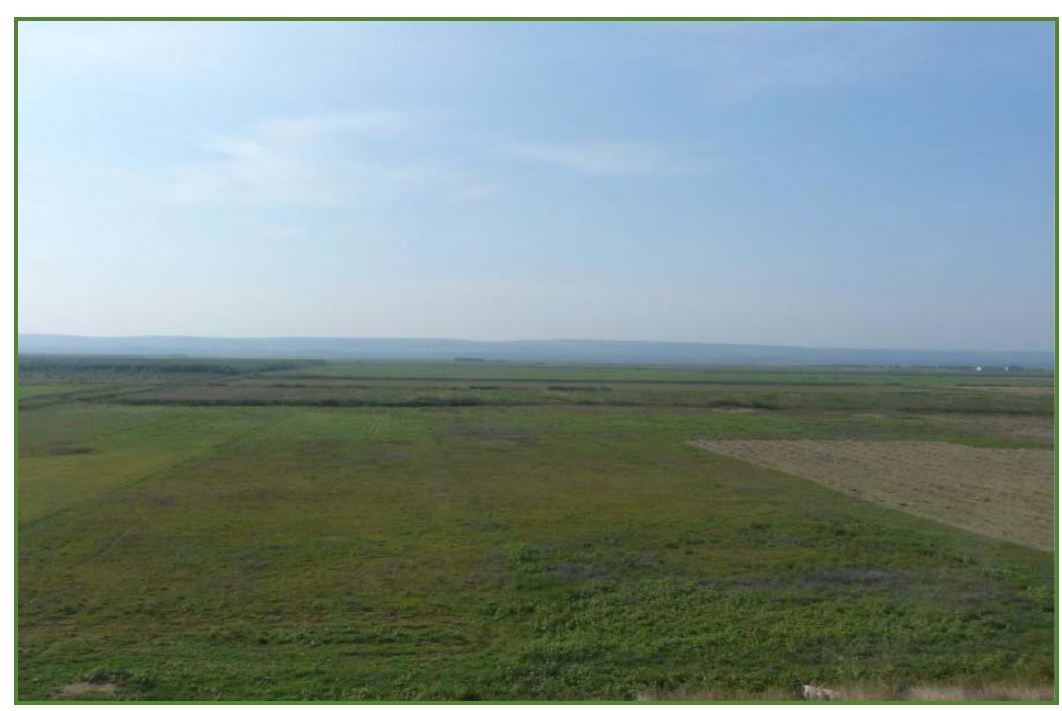

Figure 7. Entic aluviosol in Olt floodplain

Texture is clay (52-70.4\% clay) (Table 3), soil reaction is weakly-strong alkaline $(\mathrm{pH}=8.0-9.1)$. The humus content is medium in the surface horizon $(2.4 \%)$ and the nutrient supply is medium with mobile phosphorus (26 ppm) and the one with mobile potassium is high (240 ppm) (Table 4).

Tabel 3. Granulometric composition of entic aluviosols

\begin{tabular}{|c|c|c|c|c|c|}
\hline \multirow{2}{*}{ Horizon } & \multirow{2}{*}{$\begin{array}{c}\text { Depth } \\
\text { (cm) }\end{array}$} & \multicolumn{4}{|c|}{ Granulometry } \\
\cline { 3 - 6 } & $\mathbf{< . 0 0 2} \mathbf{~ m m}$ & $\mathbf{0 . 0 0 2 - 0 . 0 2} \mathbf{~ m m}$ & $\mathbf{0 . 0 2 - 0 . 2} \mathbf{~ m m}$ & $\mathbf{0 . 2 - 2 . 0} \mathbf{~ m m}$ \\
\hline Ao & $0-25$ & 52.0 & 23.5 & 23.3 & 1.2 \\
\hline AC & $25-57$ & 70.4 & 11.8 & 11.8 & 0.3 \\
\hline $\mathrm{C}_{1}$ & $57-90$ & 65.0 & 16.6 & 16.6 & 0.4 \\
\hline $\mathrm{C}_{2}$ & $90-160$ & 53.4 & 30.8 & 30.8 & 1.3 \\
\hline
\end{tabular}


Table 4. Chemical properties of entic aluviosols

\begin{tabular}{|c|c|c|c|c|c|}
\hline Horizon & $\begin{array}{c}\text { Depth } \\
\mathbf{( c m )}\end{array}$ & $\begin{array}{c}\mathbf{p H} \\
\mathbf{( \mathbf { H } _ { 2 } \mathbf { O } )}\end{array}$ & $\begin{array}{c}\text { Humus } \\
\mathbf{\%}\end{array}$ & $\begin{array}{c}\text { Mobile P } \\
\mathbf{( p p m )}\end{array}$ & $\begin{array}{c}\text { Mobile K } \\
\mathbf{( p p m )}\end{array}$ \\
\hline Ao & $0-25$ & 8.0 & 2.4 & 26 & 240 \\
\hline $\mathrm{AC}$ & $25-57$ & 8.3 & 2.1 & 23 & 220 \\
\hline $\mathrm{C}_{1}$ & $57-90$ & 8.9 & 1.9 & 19 & 195 \\
\hline $\mathrm{C}_{2}$ & $90-160$ & 9.1 & 1.7 & 15 & 186 \\
\hline
\end{tabular}

Cernisols are represented in the researched territory by cambic chernozems, cambic gleyic chernozems and argic chernozems.

Characteristic for cernisols is the obvious accumulation of organic matter (relatively saturated in bases) at the top of the soil profile, having a diagnostic horizon of type Am, continued with the transition horizon $(\mathrm{AB}, \mathrm{AC}, \mathrm{Bv})$, having colors of Am horizon, at least at the top (on a minimum 10-15 cm) and at least on the faces of structural agregates (SRTS, 2012).

Cambic chernozems. These soils were formed under the conditions of plain relief, with a poorly sloping surface, on parental materials made up from medium-fine loess-like deposits, with groundwater depth above $10.1 \mathrm{~m}$. Presents a profile of type $A m-A B-B v-C$ well developed. Cambic chernozems have a medium texture, sandy loam and the soil reaction is weakly alkaline ( $\mathrm{pH}=7.0-7.6)$. Nutrient supply is medium with total nitrogen (11.8-12.4\%), medium phosphorus (P mobile-16-20 ppm) and high potassium (K mobile-190-230 ppm) (Table 5).

Table 5. Physical and chemical properties of cambic chernozems

\begin{tabular}{|c|c|c|c|c|c|c|c|}
\hline Horizon & $\begin{array}{c}\text { Depth } \\
\text { (cm) }\end{array}$ & $\begin{array}{l}\text { Clay } \\
<\quad 0.002 \\
\text { mm }\end{array}$ & $\begin{array}{c}\mathbf{p H} \\
\left(\mathbf{H}_{2} \mathrm{O}\right)\end{array}$ & $\begin{array}{c}\text { Humus } \\
\%\end{array}$ & $\begin{array}{c}\text { Total } \\
\text { Nitrogen } \\
\%\end{array}$ & $\begin{array}{c}\text { Mobile P } \\
\text { (ppm) }\end{array}$ & $\begin{array}{c}\text { Mobile } \\
\text { K (ppm) }\end{array}$ \\
\hline $\mathrm{Am}$ & $0-35$ & 19.0 & 7.0 & 3.5 & 12.6 & 20 & 230 \\
\hline $\mathrm{AB}$ & $35-53$ & 26.4 & 7.4 & 3.2 & 12.3 & 18 & 220 \\
\hline $\mathrm{Bv}$ & $53-97$ & 21.4 & 7.5 & 2.8 & 12.0 & 17 & 200 \\
\hline $\mathrm{C}$ & $97-120$ & 15.5 & 7.6 & 1.9 & 11.8 & 16 & 190 \\
\hline
\end{tabular}

Cambic gleyic chernozems formed under the conditions of a plain relief slightly depressionary, on parental materials consisting of loess-like deposits, with the depth of groundwater between 3-5 m. Presents a profile of type $A m-B v-C k G o x$ or CcaGox well developed. Texture is clay loam (33-45\% clay) and the soil reaction is weakly acidic $(\mathrm{pH}=6.6)$. The humus content is medium in the surface horizon $(2.7 \%)$ and the supply of soil with total nitrogen is weak (10.7-11.6\%). Supplying the soil with phosphorus is medium ( $\mathrm{P}$ mobile-18 ppm) and potassium is high (K mobile-203 ppm).

Argic chernozems were formed under the conditions a plain relief on quasi-horizontal surfaces (predominantly between 1-2\%), with bumps between 10-20 cm, on loess-like 
deposits, the depth of groundwater between 7-8 m (Figure 8). Presents a profile of type $A m-A B-B t-C k$ or $C c a$ well developed. Texture is loamy (21-32\% clay) and the soil reaction is weakly acidic $(\mathrm{pH}=6.1)$. The humus content is medium in the surface horizon $(2.9 \%)$ and the supply of soil with total nitrogen is medium (11.3-11.5\%). The supply of the soil with mobile phosphorus is medium (25.6 ppm) and the one with mobile potassium is high (280 ppm).

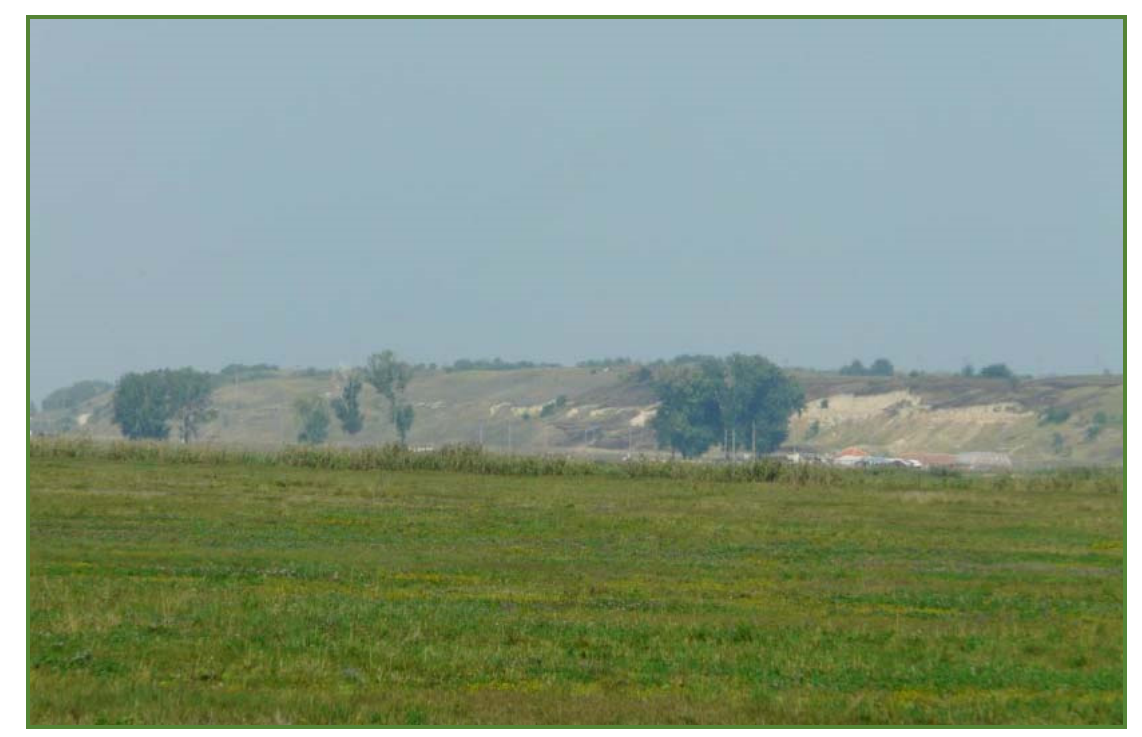

Figure 8. Argic chernozems in northwest of Locality Daneasa

Luvisols are represented in the territory investigated by reddish preluvosols.

Reddish preluvosols appear widespread within a flat relief, relatively drained, on loess-like materials, with a reddish hue due to a content slightly higher than unhydrated iron oxides influencing the color of the soil, with the depth of groundwater between 7-8 $\mathrm{m}$.

They were formed as a result of processes clay migration and weak bioaccumulation processes resulting in little humus, of poor quality. Presents a profile of type $A p-A o-A B-B t_{1}-B t_{2}-B t_{3}-\mathrm{C}$ deeply developed. The texture is clay loamy in the surface horizon (30.1-41.2\%) and the soil reaction is weakly acidic $(\mathrm{pH}=6.1-6.7 \%)$ (Table 6). Humus content is small in surface horizon $(2.3 \%)$ and decreases on profile, humus reserve is moderate $(140 \mathrm{t} / \mathrm{ha})$. The supply of soil with total nitrogen is low $(0.118 \%)$. The supply of phosphorus and mobile potassium to the soil is also small (Mobile P-12 ppm; K mobile-102 ppm).

Table 6. Physical and chemical properties of reddish preluvosols

\begin{tabular}{|c|c|c|c|c|c|c|c|}
\hline Horizon & $\begin{array}{c}\text { Depth } \\
\mathbf{( c m )}\end{array}$ & $\begin{array}{c}\text { Clay } \\
\mathbf{2 0 . 0 0 2} \\
\mathbf{m m}\end{array}$ & $\begin{array}{c}\mathbf{p H} \\
\mathbf{( \mathbf { H } _ { 2 } \mathbf { O } )}\end{array}$ & $\begin{array}{c}\text { Humus } \\
\mathbf{\%}\end{array}$ & $\begin{array}{c}\text { Total } \\
\text { Nitrogen } \\
\mathbf{\%}\end{array}$ & $\begin{array}{c}\text { Mobile } \\
\mathbf{P}(\mathbf{p p m})\end{array}$ & $\begin{array}{c}\text { Mobile } \\
\text { K (ppm) }\end{array}$ \\
\hline $\mathrm{Ap}$ & $0-22$ & 30.1 & 6.2 & 2.3 & 0.118 & 12 & 102 \\
\hline $\mathrm{Ao}$ & $22-35$ & 30.6 & 6.1 & 2.1 & 0.094 & 10 & 99 \\
\hline $\mathrm{AB}$ & $35-58$ & 33.8 & 6.7 & 1.6 & - & 8 & 97 \\
\hline
\end{tabular}




\begin{tabular}{|c|c|c|c|c|c|c|c|}
\hline $\mathrm{Bt}_{1}$ & $58-90$ & 41.2 & 6.5 & 1.4 & - & 6 & 95 \\
\hline $\mathrm{Bt}_{2}$ & $90-130$ & 38.7 & 6.6 & 0.8 & - & - & 94 \\
\hline $\mathrm{Bt}_{3}$ & $130-170$ & 40.2 & 6.7 & 0.4 & - & - & - \\
\hline
\end{tabular}

Hydrisols are formed as a result of prolonged excess moisture, with the appearance of gleyic properties $(\mathrm{Gr})$ or intense stagnic (W), starting from the first $50 \mathrm{~cm}$. They are represented within the territory studied by typical gleiosols. These soils were formed under the conditions of a floodplain relief represented by micro-depression zones, on parental materials made up of alluvial deposits, with the depth of groundwater of 0.81-1.00 m. Presents a profile of type Ao-AGox-Gox-Gr ${ }_{1}-G r_{2}$ moderately developed. Texture is clay (27.9-31.1\%) and the soil reaction is strongly acidic in the surface horizon $(\mathrm{pH}=4.9)$. Humus content is low in surface horizon (2.6\%) and decreases on the profile and the supply of soil with total nitrogen is medium on profile (0.180-0.160) (Table 7).

Table 7. Physical and chemical properties of typical gleiosols

\begin{tabular}{|c|c|c|c|c|c|}
\hline Horizon & $\begin{array}{c}\text { Depth } \\
\mathbf{( c m )}\end{array}$ & $\begin{array}{c}\text { Clay } \\
<\mathbf{0 . 0 0 2} \mathbf{~ m m}\end{array}$ & $\begin{array}{c}\mathbf{p H} \\
\mathbf{( \mathbf { H } _ { \mathbf { 2 } } \mathbf { O } )}\end{array}$ & $\begin{array}{c}\text { Humus } \\
\mathbf{\%}\end{array}$ & $\begin{array}{c}\text { Total Nitrogen } \\
\mathbf{\%}\end{array}$ \\
\hline Ao & $0-15$ & 31.1 & 4.9 & 2.6 & 0.180 \\
\hline AGox & $20-30$ & 29.4 & 5.3 & 2.1 & 0.160 \\
\hline Gox & $33-45$ & 27.9 & 5.5 & 1.3 & - \\
\hline Gr$_{1}$ & $45-90$ & 36.5 & 5.7 & 0.3 & - \\
\hline Gr$_{2}$ & $90-125$ & 30.5 & 5.1 & 0.2 & - \\
\hline
\end{tabular}

Salsodisols have characteristics strongly influenced by the presence of easily soluble salts. Therefore, in the territory under investigation are represented by typical solonetz.

Typical solonetz were formed under the conditions of a floodplain relief, represented by slight micro-depression areas insufficiently drained, on parental materials made up of alluvial deposits, with the depth of groundwater between 1.01-2.00 m. Presents a profile of type Ao-Btna-C or CGox well developed. Texture is clay (36.4-59.8\%) and the soil reaction is strongly alkaline $(\mathrm{pH}=8.5-9.5)$.

As for humus, it varies within very wide limits, generally showing good values in the first 20-30 cm, but is mostly saturated with sodium ions $\left(\mathrm{Na}^{+}\right)$, resulting in unfavorable properties. Presents small content nutrients (Total nitrogen less than 1\%; P-20 ppm and K-45 ppm) and reduced microbiological activity.

\section{Conclusions}

The territory under investigation refers to the locality Daneasa in Olt County, which from a geomorphological point of view belongs to the Boianu Plain, a subunit of the Romanian Plain. The limiting factors of agricultural production are the results of the conditions of relief and parental materials, climate, groundwater, as well as vegetation. 
A special contribution in the increase of the negative effects was also the anthropogenic activity, due to which, by improper soil management use of utilization agricole (mechanical work performed on soils with high humidity, fertilizations with predominantly acidic chemicals, non-differentiated fertilizations, lack of organic fertilization, works performed perpendicular to level curves) it has come to be that the productive potential of soils in the researched territory be greatly diminished.

In order to eliminate the negative effects of limiting factors in agricultural production and thereby improving the productive potential of Locality Daneasa, propose a series hydroameliorative and pedoameliorative works. It is necessary for these ameliorative works to be performed both singularly, and combined with each other. The order of their execution is recommended to be:

- deep-watering works for the creation of an air and water regime appropriate in the case of soils clay loam-clay texture (entic aluviosols, cambic gleyic chernozems, reddish preluvosols, typical gleiosols and typical solonetz);

- organic and mineral fertilization works in the case of soils with a varied texture, from the soil classes: protisols, cernisols, luvisols, hydrisols and salsodisols;

- $\quad$ surface drainage works to control and prevent excess moisture in soils with groundwater located at low depth (entic aluviosols, cambic gleyic chernozems, typical gleiosols and typical solonetz)

- $\quad$ work to prevent soil erosion in the case of those located on the slopes (eutric regosols)

\section{Acknowledgments}

I am very thankful to Department research in soil science, agrochemical and environmental protection, Laboratory of soil sciences and sustainable development for providing the necessary facilities to carry out this work through Research contract No. 12/2020.

\section{References}

Cotet, P. (1976). Romanian Plain. Integrated geomorphology study. Publisher Ceres, Bucharest.

Florea, N., Munteanu, I., Rusu, C., Dumitru, M., Ianoş, Gh., Răducu, Daniela, Rogobete, Gh. \& Țărău, D. (2012). Romanian System of Soil Taxonomy. Sitech Publishing House, Bucharest, 206.

Ispas, Şt., \& Stănilă, Anca-Luiza (2015). Soils Romania. Publisher Valahia University Press, Targoviste, 246.

Posea, Gr., \& Cruceru, N. (2005). Geomorphology Romania. Romania for Tomorrow Publishing House, Bucharest, 364.

Stănilă, Anca-Luiza \& Parichi, M. (2005). Glossary of soil science. Romania for Tomorrow Publishing House, Bucharest, 108.

Stănilă, Anca-Luiza. (2006). Biogeography. Romania for Tomorrow Publishing House, Bucharest, 254.

Stănilă, Anca-Luiza, Parichi, M., \& Ursaru, P. (2010). Pedogeographical observations in the Plain between the Jiu and the Danube. Proceedings. USAMV Bucharest, Series A, Vol. LIII. 
(1974). Romanian soil map, scale 1:200.000, sheet Slatina. ICPA, Bucharest.

(1987). Methodology development of soil studies (3 Volume). ICPA, Bucharest, 726.

(2008). The climate of Romania. National Meteorological Administration. Romanian Academy Publishing House, Bucharest, 365.

\section{Copyright Disclaimer}

Copyright reserved by the author(s).

This article is an open-access article distributed under the terms and conditions of the Creative Commons Attribution license (http://creativecommons.org/licenses/by/4.0/). 